\title{
Epistemic Communities Facing a New Type of Agora? Centres of Science, Technology and Innovation as Defining the New Research Landscape in Finland
}

\author{
by Seppo Poutanen and Anne Kovalainen \\ University of Turku
}

Sociological Research Online, 15 (2) 12

$<$ http://unw. socresonline.org.uk/15/2/12.htm/>

$10.5153 /$ sro. 2143

Received: 17 Aug 2009 Accepted: 5 Mar 2010 Published: 20 May 2010

\begin{abstract}
We analyse the question of what role and positions epistemic communities have in the agora, and more specifically in the new mediating organizations that are established at the interface of the state, businesses and universities. These new organizational structures embody the present politics of knowledge that reign in national science policy globally. The new organizational structures, as potentially new agoras, also epitomize several of the changes that have taken place in the science and industry landscape of the past decades all over Europe and the world. We are interested in understanding how epistemic communities are situated vis-à-vis agora in knowledge production. The empirical example comes from Finland, where major new institutional reforms in science policy, the new strategic centres of science, technology and innovations, have been implemented to create possibilities for new knowledge creation and new product and service development. These centres of science, technology and innovations (CSTIs) were originally planned as functioning agoras, open, simultaneous and joint platforms for the state, businesses, researchers and universities. In the article we show how the organizational structure and decision making processes adopted in the CSTIs have changed the original idea of agora, thus changing also the position of epistemic communities involved. In the process, we evaluate Nowotny's interpretation of agora.
\end{abstract}

\section{Keywords: Epistemic Communities, Agora, Science Policy, Finland, Research Landscape, STS Studies, Critical Research, Qualitative Study, Company, Power}

\section{Introduction}

1.1 As researchers, how do we become socialised? Becoming a member of a research community takes place through various kinds of institutional structure, but most of all, through epistemic communities. As a concept, 'epistemic community' has a wide range of meanings in sociology and in philosophy, ranging from the social epistemological view of Helen E. Longino (2002) to the practical work cultures of Karin KnorrCetina (1999) and the influential policy actors of Peter Haas (1992). Epistemic communities are created, located, established and renewed within and through processes and institutions, networks and journals assigned to scientific knowledge production. In scientific knowledge production, epistemic communities can be seen as the key players/platforms in defining what becomes new knowledge and worth researching. In this article, we discuss the concept of the epistemic community in two ways. Firstly, we relate the concept to that of agora. The concept of agora refers both to a classical place ${ }^{[1]}$ and to an important multi-purpose metaphor, but now it broadly means a public space devoted to multifaceted free discussion on science and science policy. Secondly, we examine the ways in which an epistemic community potentially opens up and makes it possible to influence the research agenda in a changing research policy landscape.

1.2 The general approach to epistemic community emphasises the voluntary and intellectual nature of such membership through research activities (e.g. Knorr-Cetina, 1999). One's own research interests define the communities where 'membership' - be it short-term, virtual or long lasting - is relevant. Those who share epistemic communities most often share research interests, methods and epistemic approaches, and work through conceptual and theoretical schemes which are discussed, debated and related to in many ways through those communities. On the other hand, epistemic communities work collectively, i.e. through peer review, publications and conferences, shaping and directing the common understanding of the research within the field, and thus building a normatively science-based or research-question-based joint understanding of the relevant kind of knowledge.

1.3 Epistemic communities have been analysed through a variety of prisms, mostly as communities with shared values or research interests, work cultures and practices of scientific work ('laboratory life', e.g. Knorr-Cetina, 1999; Latour \& Woolgar, 1991), but also as communities sharing 'epistemic living spaces': 
micro-level work related to multidimensional structures and practices (see several authors and contributors in Felt, 2009). Overall, the focus of interest and analysis of epistemic communities has been at the microlevel, i.e. in the practices and detailed processes of work through ethnographically inspired research. But epistemic communities can also work detached from the everyday practices of working laboratory life. They can have stronger or more coherent 'programmes', a more formalised presence in the science community, and thus, attain influence and hold positions in defining knowledge boundaries and positions (e.g. Haas, 1992; Elzinga, 1993; and also Jasanoff, 1998).

1.4 However, fewer analyses view epistemic communities from the point of view of the power they exert and the positions they have in the articulation of science policies and science policies in the making. This might be due to the emphasis on science in the making, laboratory life, which has generated many studies within sociological study of science (STS) research. From the STS point of view, the ways in which epistemic communities such as groups, associations or societies become influential or lose or maintain their influence in both science policy and in defining research resource allocation, for example, are especially interesting as they relate to national and international science policies and structural changes in science governance. Equally interesting are the ways in which epistemic communities can be understood simultaneously as mechanisms contouring and redefining the internal coherence of the field of science in question.

\section{Key concepts and approach to analysis}

2.1 In this article, we are interested in analysing the question of what role and positions epistemic communities have in the agora, and more specifically in the new mediating organisations that are established at the interface of the state, businesses and universities. These new organisational structures embody the present politics of knowledge that reign in national science policy globally. Our example comes from Finland. The new organisational structures, which in science policy documents are typically outlined as virtual agoras, also epitomise several of the changes that have taken place in the science and industry landscapes of recent decades all over Europe and the world (e.g. Deem et al., 2007), including the idea of the co-production of knowledge (Nowotny et al., 2001; Etzkowitz \& Leydesdorff, 2000; and Jasanoff, 2006).

2.2 The argued-for changes in the ways knowledge is being produced as context-driven, problem-focused and interdisciplinary or transdisciplinary, distinguished from traditional research, which Gibbons et al. (1994) presented in a widely debated form (e.g. Pestre, 2000, 2003; and Fuller, 2002) as "mode 1", which is academic, investigator-initiated and discipline-based knowledge production, while "mode 2 " is more contemporary, problem-focused and interdisciplinary. This idea is further developed to include a distinguished space for co-operational knowledge production, which is thus called 'agora' (Nowotny et al., 2001). For the authors, the agora means specifically a space and place for mode 2 knowledge production, as the more conventional models of how scientific knowledge is produced and translated into policy uses or innovations need to be superseded by more hybrid models. Agora is offered as such a platform, to support the mode 2 idea as an ideal organisational solution for shared and extended knowledge production and, more precisely, for transdisciplinarity (Nowotny, 2003) ${ }^{[2]}$. Agora was proposed as a new public space where multiple actors (researchers included) co-mingle to shape research agendas and make use of research results (Nowotny et al., 2001: 202).

2.3 How are different epistemic communities situated vis-à-vis agora in knowledge production? Agora, as an influential classical idea, is described by Nowotny et al. (2001) as a modern version of an ancient Greek metaphor, a structured "public space where science and society, the market and politics, co-mingle..." (2001: 203), and which is "shaped by the interaction of its actors/agents" (p. 209). According to Nowotny et al., although the agora is "a structured space, it is wrong to attempt to subdivide it again into sectors like markets, politics or media", as, according to the authors, "these forms of differentiation are beginning to break down, and to be replaced by fluid and dynamic (and pervasive) interlinkages" (p. 209), of which some are more visible and easier to identify and recognise than others. The agora is an open space where different perspectives are brought together and are "ultimately creating different visions, values and options" (ibid.: 209). More specifically, agora in the STS literature is defined as an open and democratic platform or process, carrying the characteristics of bottom-up approaches to research, which are typical of the influence patterns of epistemic communities, with shared and equally vested interests by all participants, and transparency throughout the different activities (Barré, 2001, Frederiksen et al., 2003).

2.4 The fact that the privatisation of knowledge or market relations in knowledge production is not strongly evident in the idea of agora should be noted. The way Nowotny et al. (2001) present agora plays down several key elements, such as the differentiation and conflict of interest stemming from differences in agendas and epistemic commitments, while it emphasises the consensus view among actors and stakeholders. More problematically, the question of power asymmetries is not taken up, although they are built into the idea of agora. We will come back to this important issue later in our empirical material and discussion. 
analysis of the role of science and the scientific community in defining international politics. In Haas' description, an epistemic community shares values and a normative understanding as the basis for political actions, which become defined through research results (1992: 3-4; 16). For Haas, politics - and society at large - can and should be changed through knowledge. This is promoted by the shared criteria for knowledge production (1992: 34).

2.6 Contrary to Haas' strong, traditional science-based idea of the epistemic community, post-structural research and contemporary social epistemology have opened up differing views on epistemic communities: an epistemic community can be built up virtually as well as corporeally, but almost always by emphasising the social nature of knowledge (e.g. Longino, 2002; Kitcher, 2001; Solomon, 2001). In particular, the sociality, contextuality and multiplicity inherent in knowledge building, lead to a very different, loosely structured idea of epistemic communities, and also of the possibility of their influencing science policy. According to Longino (2002), the key to epistemic communities is that they extend over time and over contextualised collaboration. In Longino's definition of the epistemic community there is no single direct relationship to science policy activism. The epistemic community exists despite this lack of relationship: the logic of science and socialised knowledge create epistemic communities, not extra-science related matters such as politics. While Longino emphasises the social epistemological questions in her view of the epistemic community, Knorr-Cetina writes about epistemic cultures as communities at the workplace level, embedded in the micro-practices of workplace cultures (1999).

2.7 Epistemic communities can be argued to have a significant, if not the formative, role in the definition and formation of research-related policies and practices, as well as in the formation of science policies (Haas, 1992; Longino, 2002). How are these epistemic communities, given the different understandings of them, related to potential agoras? Our interest in this article lies in the analysis of the possibilities epistemic communities have in science policy. We will critically valorise the idea of agora and claim that while the idea of agora is grandiose and builds upon the idea of openness and transparency, it nevertheless lacks realism in relation to the relevant institutional arrangements, and thus shuns the possible presence and influence of epistemic communities. We argue that while the idea of agora is most often introduced as an open space for science to develop through various agencies' collaborative actions (university, industry, state), it is not in fact that open, and the collaboration is often encoded through epistemic differences in interests.

2.8 The empirical example we use to assess the realisability of an agora as a new structure and process comes from Finland, where major new institutional reform in science policy, via new strategic centres of science, technology and innovation, has been established and implemented in order to create innovative possibilities for new knowledge creation and new product and service development. These centres of science, technology and innovation (CSTIs) have been, according to public science policy declarations, organised according to principles that ought to make them equivalent to agoras: simultaneous, open, democratic and joint platforms for the state, businesses and universities, both in terms of funding research activities and shaping future research agendas. Because the poststructuralist and social epistemological definitions allow us to see state and business bodies also as epistemic communities to some extent, in addition to the 'traditional' epistemic communities such as researchers and universities, it becomes pertinent to ask what roles and positions different epistemic communities have in the postulated agora.

2.9 The data presented here consist of documentary materials. We gathered national science policy texts and statements dealing with Finnish research policy during 2000-2009, of which we use part in the analysis (Table 2). Evaluations, assessments, plans and reports from the ministries and national funding agencies are analysed through close reading and critical textual analysis; contents, internal consistencies (or their lack) and interconnections between statements were all foci of study. The policy documents are published mainly by the Ministry of Education, the Science and Technology Policy Council (the highest governing policy organisation chaired by the Prime Minister), the Academy of Finland (the Finnish research council), and TEKES, (the Finnish Funding Agency for Technology and Innovation). All the documents addressed the changes in university-industry-government relations and advocated closer relations between universities and industry.

2.10 We will first describe the birth of CSTls within the Finnish research landscape, give an overall view of CSTIs, and more specifically, give an example of the organisational structure and decision-making process of one of these CSTIs. After that, we provide more theoretical discussion and conclusions. As researchers we are not directly or indirectly involved with any of the CSTls. By applying systematic close reading and textual analysis to the salient public documents produced by the key designers of science policy, we have reconstructed the main narrative and subsequent features of the developments. Science policy documents can themselves be regarded as narratives of how science "should" be done. At the same time, science policy documents have an impact not only on the academic world (evaluations of research might influence funding decisions, etc.) and practices (how science should be organised and carried out), but they also represent "Finnish education and science" to a larger societal audience.

The Birth of Strategic Centres for Science, Technology and Innovation in Finland 
3.1 What happens in a small, open economy with a strong dependence on global markets where the national "return on R\&D investment" has not been able to produce new global success stories comparable to Nokia, and where publicly funded basic research activities are fragmented among over 20 universities and 29 polytechnics for a population of 5.1 million inhabitants? In Finland, R\&D investment is approximately $3.5 \%$ of GNP (2007), that is, approximately EUR 6.2 billion annually. Of this funding, the share of public expenditure has been less than 30\% (EUR 1.7 billion), while companies cover EUR 4.5 billion (Statistics Finland, 2009). Companies' share of R\&D funding was even higher during 2008, but not for universities' share: approximately EUR 10 million less R\&D expenditure than in the previous year was recorded in statistics for the public sector in 2008. In practice, the relatively low share of public expenditure increased the pressure for short-term R\&D activities in the private sector. The national-level need was articulated by government officials, ministries and the Research and Innovation Council, which has a pivotal role in promoting science and technology and relevant education, to make the research funding system, and related to that, the innovation system, more 'responsive' in terms of efficient outcomes, applicable and innovative research results. This led to high-level soul-searching and finally to a large-scale change in research funding and organisation nationally. How did this take place, and how were epistemic communities involved in this activity?

3.2 The aspired-to policy reorientation in Finland is a not solitary or unique phenomenon but follows panEuropean, even global, trends in the demand for greater efficiency, accountability and control in research systems (e.g. Power, 1997; Elzinga, 2004; and Webster, 2007). These changes were originally discussed in terms of 'national systems of innovation' (e.g. Nelson, 1993), 'research systems in transition' (Ziman, 1994), or even 'the post-modern research system' (Rip \& van der Meulen, 1996). These works discuss the idea of flux and emphasise the role of knowledge in the economy and society. In order to explain reorganisations in university-industry-government relations, one would need to turn back to sociological theories of institutional power, retention and control. In this article, we will focus on organisational structure, epistemic communities and agora, which all relate to the aforementioned concepts.

3.3 "A fragmented structure is unable to generate high-quality competence and research." (Finland's Competence, 2004: 29) was the message demanding corrections to the national research landscape. A rapid reaction to the assumed 'non-productivity' of the research system and the declining outputs from the scattered research funding system followed from ministry and governmental levels (Table 2). Without presenting evidence to back up the statements, the reports stated the lack of response in terms of desired outcomes in the following tone: "The problems of the Finnish university system have to do with quality and internationalization." (ibid. 2004: 30). This same argument was voiced about the whole research funding system, thus leading to the demand for more fundamental change: "A small country can only reach the top in a handful of research fields. Solving the problems requires changes to the overall financing of the university system, its sources of funding, the incentives provided to universities and students, and the division of labour between universities and their specialization." (ibid. 2004: 29).

3.4 Several reports and 'white papers' and finally, a government resolution on the structural development of the public research system and a high-level action plan led by the Prime Minister followed. All of these emphasised the need for a new, open, shared activity, which would gather the best researchers and research communities for the joint effort, e.g. in a report on the internationalisation of Finnish knowledge and innovation system: "Research organisations must be developed as active and dynamic cooperation partners for business and industry." (Knowledge... 2003: 2). This action plan outlined a profound and prominent change in the Finnish research funding and R\&D landscape. The plan introduced new mediating, open agencies, organisations that would serve as shared platforms for universities, businesses, third-sector institutions and governmental bodies. "A national strategy for creating and strengthening internationally competitive clusters of competence and centres of excellence must be drawn up." (Finland's Competence 2004: 29). The high-level action plan repeated much of the rhetoric of earlier documentation, only in a more imperative manner, and also in terms of budget steering, as these excerpts show: "The implementation should focus on the essential and deliberately chosen key areas of competence with regard to the economy and society." (Science..., 2006: 9) and "The Science and Technology Policy council's report on Strategic Centres of Excellence and infrastructure policy will concretely steer the allocation of funding." (ibid. 2006: 13).

3.5 The high-level action plan was implemented during the period 2006-2009. The key, closely linked elements were the establishment of strategic Centres for Science, Technology and Innovation (CSTI) and the 2009 renewal of the Universities Act, which governs the Finnish higher education system. The nationallevel change that has taken place, from open and diffuse R\&D funding to more strategic and top-down formed clusters, such as CSTIs, has required changes to funding for and in the definition of what is understood as clustering of scientific knowledge. The change also questions the idea of 'usability of scientific knowledge', and the valuation of knowledge in terms of economic returns. In the restructuring process of science funding at the national level, the government commissioned several reports concerning the public research system, the internationalisation of science and technology in Finland and, on the basis of these reports, drew up a national strategy "for creating and reinforcing internationally competitive science and technology clusters and centres of excellence" (Academy of Finland, 2009), which was accepted by 
the government. ${ }^{[3]}$ The idea of CSTls was launched as an open forum for the best Finland-based enterprises, universities, research institutes and financing organizations to collaborate, as agoras where epistemic communities could have a significant role, thus "attracting innovative and globally leading enterprises and top-ranking experts to Finland". (Strategic.., 2006: 1).

3.6 The idea of CSTIs was subsequently adopted and adapted at the national level through a rapid process of decisions and allocation of resources. Our analysis shows that the idea of CSTIs was introduced early on in implementation of the overall changes due to: 1) the increasing demand for international competitiveness of national economy, 2) the scattered resources of research system, and 3) the inability of universities to 'act alone' in issues of R\&D activities. In 2006, the Science and Technology Policy Council, which is the highest national R\&D organisation, chaired by the Prime Minister and working under the government, approved the development of CSTls and national infrastructure. ${ }^{[4]}$ Work then started on establishing strategic CSTIs in areas of expertise that were considered crucial for the future of both the business sector and Finnish society at large.

3.7 The principles of the CSTIs require larger collaborative forces joining their activities together in order to become recognised by the government and named as 'CSTIs'. CSTIs serve as examples of public-private partnerships as closer cooperation between public, private and foreign research financing is required from funding bodies such as the Academy of Finland, TEKES and universities, together with the Innovation Fund and also other funding organisations. TEKES gives priority to CSTI applications in its funding. The Academy of Finland, which is the primary funding agency of basic research, takes into account CSTI research applications. According to the Academy of Finland's research funding principles, the recognition of a research application as a CSTI-related research project might give the application a leading position in relation to another application with the same evaluation grade, but recognition of an application as CSTIrelated research does not automatically ensure research funding. For TEKES, which is the primary funding agency for applied research, the funding of CSTI is guaranteed through budgetary measures. These moves represent a major shift in the allocation of funding for research in Finland.

3.8 Therefore, the valuation of applications of either CSTI or non-CSTI-related activity gives a strong signal to the research community that it might be sensible to become attached to CSTI activities. Are these CSTI activities open to all researchers alike? Can any researcher mark his/her application as CSTI-related, and thus have priority? In other words, are CSTIs agora-like public spaces where science and society, markets and politics co-mingle in the way defined by Nowotny et al. (2001)? For the purposes of this article, we need to reply positively, as CSTIs, when judged through the officially stated science policy goals, seem to fulfil the idea presented by Nowotny et al. (2001), and later redefined by Nowotny (2003), by offering an open entrance for the planning and designing of CSTIs. The openness and agora-like nature of the CSTls were strongly present during the design and the planning processes of CSTIs, according to our policy document analysis. The overall aim of CSTIs of establishing and reinforcing long term research cooperation between academia and industry was seen at best as based on "flexible, free collaboration instead of formal agreements. There is no need to change this policy, as researchers' and research groups' networks (i.e. epistemic communities) are central mechanisms in creation, transfer and utilization of new knowledge." (Internationalization..., 2006: 8)

3.9 The overall R\&D policy intent with CSTls is to produce entities that are larger, "in order to improve the impact of R\&D and innovation financing" (Ministry of Education, 2005a). The underlying rationale for the structural change was based on the decision by the Finnish government on the structural concentration and development of the public research system, including the structural changes to the higher education system, in order to create internationally competitive science, innovation and technology know-how (Ministry of Education, 2005b). As mentioned, national competitiveness on a global scale was expressed as the motive and organising principle for the strategic concentration of national-level R\&D investment. This development is partly articulated in Slaughter and Leslie (1997) as a manifestation of academic capitalism, with macro-level background conditions in globalisation pressures and competition within academia. As part of the larger structural change, the role and position of universities as independent economic entities have been increased through the legislative changes during 2009, and larger universities through mergers and collaboration contracts which were subsequently established.

\section{Choosing the key national areas for the CSTIs}

4.1 During 2009, the high-level identification process for possible nationally strategic fields as centres from an open application procedure to their recognition and naming as CSTls by the Government's high-level science policy commission - led to the establishment of six national CSTIs. The six CSTIs are in the areas where "the potential to be one of the leading centres in the world" has been identified as existing (Academy of Finland, 2009: 5). The naming of a unit as a CSTI is not directly a funding decision as such, but the naming will channel the funding allocation in many ways, both directly and indirectly. The criteria for the centres were, among other things: that they have considerable potential at the national level; that they are large enough when measured according to personnel and national-level R\&D volume; and that they are practice-driven, multidisciplinary, virtual, collaborative, and innovation-based. In spring 2009 , the six chosen 
CSTI areas were: (i) energy and the environment, (ii) metal products and mechanical engineering, (iii) forest products and the forest cluster, (iv) health and well-being, (v) the built environment, and (vi) the information and communication industry and services (Academy of Finland, 2009). The aim with these six CSTls was to "bring together a variety of competencies in diverse networks which can help speed up innovation activity, pursue global breakthroughs and make Finland an attractive partner." (TEKES, 2009: 8). A new organisational form was created within each of these areas, epitomising the close relations between the different partners, universities, the state and businesses. The organisational structure of a limited company was adopted for all of the CSTIs, so as to manage and govern their activities.

4.2 How are the CSTIs funded? The goal for the CSTIs within each of the fields is to "thoroughly renew industry clusters and to create radical innovations" (TEKES, 2009), this means that funding needs to be allocated from public R\&D funding resources, as well as from companies' own budgets. TEKES, the Finnish Funding Agency for Technology and Innovation, is the main public funding organisation for research, development and innovation in Finland. TEKES is committed to CSTI activities and will finance the centres' research programmes and projects. The annual total spending of TEKES for all R\&D projects at companies, universities and research institutes is approximately EUR 516 million (2008), and it is estimated that it can use up to half of the annual budget to fund CSTI activities in the future (TEKES, 2009). As the CSTIs were launched mainly during 2009, the 2009 budget reached only EUR 10 million. By way of comparison, the Academy of Finland, which is the prime funding agency for basic research in Finland, made research funding decisions to a total value of EUR 287 million in 2008 . Over $90 \%$ of the funding decisions made by the Academy are made on the basis of the scholarly, international peer review process. For TEKES, internal evaluation is used as the evaluation mechanism, and no international peer review is used.

4.3 Within the six CSTI areas, new public-private partnerships and rules and regulations for closer collaboration have been established, and the organisational structure of 'non-profit' limited companies has been adopted as the operating mode. At the core of CSTI activity is an organisational structure, a company that organises research programmes, brings together the key agencies, and acts as a core node for research networks among those participating in CSTls. Etzkowitz and Leydesdorff (2000) describe this structure of organisation as a 'quasi-firm'. The development of national innovation systems is reflected in the varying institutional arrangements of university-industry-government relations, such as the CSTI structure. Why is the chosen organisational structure so important? The question of 'agora' comes into play here. The organisational structure means, in practice, that the agencies participating in limited company formation as shareholders also govern and carry responsibility for the directions given to and the content of research programmes. To begin with, the owners/shareholders generate the Strategic Research Agenda (SRA) together, thus giving guidelines for its future activities. The ownership of shares in the CSTI company thus enables the owners of the company (universities, firms and public bodies) to become members of the board of the CSTI company, which governs the R\&D activity.

4.4 More importantly, share ownership means control and power over the strategy for research activities and funding. The board members and owners of the company are ultimately both the architects of and decisionmakers for the research strategy and financing decisions concerning the CSTI activity in question. Each CSTI company has a chief executive officer (CEO), chief technical officer (CTO), a board of directors, and some of them also have internal R\&D councils and/or steering groups for sub-programmes, consisting of the shareholders' representatives. In some of the six companies, the boards make the final funding decisions for eligible research projects. In others, steering groups within the sub-programmes consisting of the shareholders are established for that purpose. Table 1 shows the key organisational structure, annual funding volumes and board membership division in terms of gender and academic background (epistemic community) of the existing CSTIs in Finland.

\section{Strategic Centres of Science, Technology and Innovation as agora - the epistemological core of knowledge creation}

5.1 We have so far established both the origin of, and the organising process and structure of, the national CSTIs. We will now turn to describing in more detail issues of how the national R\&D investment and funding resources are allocated through and with the help of CSTIs, and how these CSTIs work in practice. Do we find epistemic communities at work in those processes? We argue that while CSTls could, in some senses, be described as the new agoras for knowledge creation (Nowotny et al., 2001: 177), to refer to a social or public space in which science interacts and is constituted, the general criteria for agora and epistemic communities in action are not fulfilled in the present day organisation of CSTIs. In fact, and regardless of Finnish science policy rhetoric, the CSTIs rather follow the so-called "Triple Helix" model, which in contrast to the thesis of mode 2 knowledge production, emphasises historical continuity in the relationships between university, industry and government, and sees 'neo-differentiation' also taking place in their functions and co-operation (Shinn, 2002: 600-606).

5.2 We will start by describing the organisational decision-making structure in CSTls, in order to explain how the research communities, understood widely as epistemic communities, become subjects in the research activities, followed by an analysis of one specific CSTI. 
5.3 While all six of the CSTls were launched during the period 2008-2009, it is too early to evaluate their research activities, results, work or indeed their potential impact on the R\&D landscape in Finland. It is possible, however, to analyse the structural change of the R\&D landscape. We will describe the organisational structure, decision making and the ways in which research is understood and defined within CSTls, in order to show how agora becomes a closed space where epistemic communities do not have the possibilities that could be assumed from agora as a platform for science

5.4 The overall aim of the CSTIs in Finland is to support the middle-term (five to ten years) research horizon with a specific focus on the applicability of joint R\&D efforts by companies and universities. They should increase research collaboration and its efficiency, and encourage the setting of more scientifically ambitious research objectives. The six CSTls function in areas that are recognised as nationally important, and are supposed to lead to future cutting-edge fields globally. While the fields of health and well-being, energy and the environment and information technology all refer to global knowledge areas, the three remaining fields, that is, forestry, metals and the built environment, are all nationally embedded in the economic history and present economic structure of Finland by their more specific content and position in society and in GDP.

5.5 For all CSTIs, joint R\&D activities are a prerequisite. In addition to collaboration, the question of cartels also becomes crucial when competition legislation criteria need to be taken into account; CSTIs need to fulfil the eligibility criteria defined in the European Commission's regulations on horizontal cooperation. The competing companies involved in the same CSTls have taken precautionary actions and measures in order to foresee possible problems. External complaints might be few as much of the research is done within the restricted external information outflow of the research projects: those outside of the CSTls do not gain full access to research done within the CSTIs.

5.6 As we mentioned earlier, shareholders are in a key position as the architects of the CSTls' activities, as only they have the power to define the research activities of the CSTIs, permit new members, etc. Thus, all the core activities of CSTIs are built around the company structure. How does the CSTI, the company, in practice then define the future R\&D activities which will be implemented in their research programme? In the formation phase of each CSTI company, the shareholders formulate a joint Strategic Research Agenda (SRA), which, in practice, articulates the joint vision of shareholders for the future research area in terms of applicable R\&D. The joint SRA deals with the shareholders' shared vision, not just a single shareholder's vision, even if it may prove to be difficult to make a clear-cut distinction between the two. The SRA provides the rationale for the more specific research programmes launched and sub-programmes within each of the CSTIs.

5.7 In principle, the development of the SRA seems to follow the main requirements of agora: all who have an interest in the agenda co-mingle and have the possibility to participate in the programme formulation at the most strategic level. Universities, as the epistemic communities, and researchers as members of epistemic communities, have thus been able to be present both in the formation phase as well as in the actual workings of the CSTI. We need to ask the question whether the SRA does represent the epistemic communities, when the majority of shareowners are companies, not universities. In the following section, we show how this decision making within the CSTI takes place in practice, and how that in effect then changes the participation possibilities of epistemic communities.

\section{The Metals Cluster as a case example of a CSTI}

5.8 FIMECC (the Finnish Metals and Engineering Competence Cluster) was established in 2008 and operates within the field of metals and engineering research, covering a large field from the shipbuilding industry to forest companies (STX Europe Ltd, Metso Ltd). A global lift and crane corporation (KONE, Konecranes Ltd) and a software design company (Tieto GMR Ltd) were also founding companies for FIMECC. FIMECC has 30 founding shareholders, of which (11) are universities / research institutes. $75 \%$ of the shares are owned by the companies, $25 \%$ are owned by research institutions. The strategy paper of FIMECC explicitly states that with any CSTI, "the industry can have stronger influence [sic] on the research themes and target setting," (FIMECC SRA, 2009: 1). [5] The vision expressed in FIMECC's SRA is that it "will create new international research networks, new top science, and new application-driven research contents. The competence and knowledge in selected focus areas will be raised to a globally leading position. The research activities are based on ambitious target-orientation, openness, dynamics, and true internationality," (ibid.: 16). The SRA defines five themes for research activities: Service business, User experience, Global networks, Intelligent solutions, and Breakthrough materials.

5.9 All five research fields cover the issues closest to the participating companies, and also their views on the future groundbreaking science areas in Finland within these fields. Basic research is mentioned only in relation to 'strategic basic research', which is defined as "something that companies can do together in order to increase the number of innovations." This can be, for example, technological platforms for applications and products (ibid.: 13). It needs to be noted that within the CSTls the understanding of 'basic 
research' is different to the mainstream definition of 'basic research' in universities: the research is neither 'free' nor 'open', but it is predetermined and predesigned, starting from the companies' strategies, and closely linked to them. In this context, 'basic' seems to mean that research may not result in immediate usability in terms of product or service innovations.

5.10 During 2009, two large research programmes within FIMECC were launched and a budget of EUR 70 million for a four-year-period, which is over 600 person-years of work, has been secured. The programmes will focus on, among other things, developing new solutions and material technology solutions for machinery (FIMECC SRA, 2009) for example, within the ship-building industry. This latter programme includes 26 companies and 11 research institutes involved in the FIMECC company, who will put the programmes into practice.

5.11 Is it possible, then, for any researcher to apply for funding or to become a member of the research programmes? Have CSTls held their original idea of openness, thus functioning as the agora? In a sense, no. Those university researchers who are not part of an institution that is a member of the CSTI can still get separate, smaller project funding if they can "sell" their research idea to any shareholder company participating in the CSTI. These researchers, however, do not have any role in setting or steering the research agenda and research programmes, so it is up to the participating companies to decide if they like the idea of the "external" researchers to the extent that they are included and adjoining as subcontractors to their own research groups.

5.12 Like any other CSTI company, FIMECC accepts new members only through a directed issue, which enables new members to become shareholders, that is, the owners of the CSTI company. The company legislative procedure gives power to the current board on whether they wish to launch a directed issue or not. Within CSTIs, no new programmes or projects can be developed without the informed consent of all shareholders. Shareholders are either informed or, in most cases, are actively involved in designing the programmes. The owners name their representatives for the research council of the CSTI (FIMECC has 33 members) and to steering groups for each programme (FIMECC has four programmes, and the size of each steering group varies between six and eight members, with the chair from the company and the majority of the steering group members representing the companies).

5.13 FIMECC applies an internal evaluation procedure on projects where absolute criteria include issues such as having more than one company involved, keeping all shareholders informed during preparations, and acting in line with the FIMECC SRA. These criteria must all be positive. With internal evaluation, then, it becomes difficult not to receive funding, when the preparatory phase requires an involvement process and negotiations with all parties concerned. In the formal evaluation form, a total of 23 questions covering six criteria, each including three to six evaluative questions, are ranked from one to five. These criteria include industrial relevance (six questions), scientific quality (three questions: "How many researchers have a scientific education?", "Do the researchers belong to the global scientific top 20 among their peers?", and "How ambitious, challenging and risky is the target?"), creation and maintenance of critical mass in Finland (four questions), international attractiveness (four questions), interactivity (four questions) and crossdisciplinarity (two questions: "Are the different scientific backgrounds cross-disciplinary?" and "Are there participants who have fruitfully different perspectives on the subject?") (FIMECC Project assessment form, 2009). In the evaluation, most emphasis is given to industrial relevance. The whole evaluation is done internally among the shareholders, and no external, international science-based peer review is used in the evaluation process. While the academics present on the board and committees within CSTI are in a minority position in all decision making, and while they are most often designing and applying funding for themselves, the epistemic communities through their academic representatives are not apparently functioning.

5.14 Within other CSTls, the procedures follow the logics of decision making and evaluation described above in the context of the FIMECC, that is, new projects are evaluated internally by the shareholders, who also might be part of the project, and in line with the internally-designed SRA. The evaluation of R\&D programme proposals is said to emphasize the strategic fit, value creation potential, environmental factors and risk factors. The hermetic evaluation process implemented within the CSTI does not allow for open or wider assessment of the research projects and research programmes, nor does it open up an avenue for non-shareholders to affect the research agenda or participate it from their own interests. The research agenda is thus closely tied to the shareholders' views, companies' needs and understanding of the field, and given the company logic it is evident that the naturally selfish motives of corporations need to be embedded in the R\&D activities of any CSTI's research agenda - no research gets funding without their consent to it, and thus some form of benefit from it.

\section{Companies as epistemic communities? The contradictory logics of markets, epistemic communities and the agora}

6.1 Having established the general operational and strategic structure of CSTls, and the logics of research funding and decision making within CSTls, we now return to the concepts of epistemic communities, agora 
and socially relevant knowledge. Is it possible to establish fields of research that would enable social significance, not in economic or market terms, but in terms of knowledge, as defined by and through the work of epistemic communities? What are the possibilities for a multiplicity of voices and positions of epistemic communities in these ostensible agoras?

6.2 The rather hermetic nature of R\&D activities within the CSTIs, when analysed by R\&D programme design, programme implementation and the evaluation procedure for projects, which all take place strictly within the CSTI, becomes reasonably clear from the short description above. The open or equal access of academics - or the wider research community - to research programme design and agenda setting is not easily achieved after the organisational structure has been selected and the limited company formation has taken place. The strategic research agenda is set and defined through a process where the consent of a majority of shareholders is needed. While the majority of shares of CSTls are owned by private companies and stock-market listed corporations, we can justifiably ask whether these projects serve the best interests of the country or the interests of those companies, who need to produce quarterly results for their own shareholders, irrespective of the origins of the ownership of shares. If we assume that the interests of the country and private companies go hand in hand, all well and good. But if we assume a national R\&D future consisting of other kinds of interests, there is a problem.

6.3 Equally closed are possibilities for ${ }^{[6]}$ the introduction of new projects or ideas to the CSTI, and the possibilities of affecting the future research agenda, based on scientific excellence that is situated outside the CSTI. The idea of access or openness is clearly problematic. The formality of assessment - all projects need to fulfil a specific set of criteria - gives reason to assume that all are treated equally. However, for example, no information is available on how the internal assessors understand the complex issue of crossdisciplinarity or other questions that call for science policy or evaluation experience. We also need to know how accurate this type of assessment, as described above, can be from the point of view of wider epistemic communities, when the majority of the assessed elements are not based on scientific but socalled 'relevance-based' criteria.

6.4 As an aside, it can be remarked that the Research Councils of the Academy of Finland give a more promising example of an agora-like platform where primarily scientific epistemic communities participate on an equal footing in research project assessment processes, as no epistemic community is restricted from applying for funding, from the programme proposal procedure, nor from the peer review system, which is based on international expertise only and which forms the basis for the funding decisions. There we see epistemic communities functioning according to something more like the original idea of the agora, and the logic of functions and agenda setting is done by one shareholder only, through its representatives, and this shareholder is the national and international research community at large.

6.5 It would be problematic to close our eyes to the issue of the majority of the CSTI share ownership being with companies. Can they even be required to participate and make decisions on a basis other than their own companies' motives when they are responsible to their own shareholders for the share dividends and principally for nothing else? Even if the CSTI companies are non-profit companies, and cannot thus generate share dividends, the status-quo of the ownership keeps the power in the hands of the original owners. Here the question of power becomes apparent - the neglected issue in the definition and use of the concept of the agora - and calls for comment. The lack of attention to power issues in the agora has been brought up in research literature by several authors (Barré, 2001; Pestre, 2003; Fuller, 2002), but no clear idea of how it can be dealt with has been offered. Our analysis suggests taking a closer look at the organisational structures and decision-making procedures as one way forward.

6.6 We wonder if the openness originally planned into the CSTls in the plans of the government as a common agenda is present. Openness is still advocated on the web-pages of all CSTls, e.g. by stating that the "opportunity to participate in projects is open to anyone". The conditions then for those who become desired participants are demarcated as a person/agency: "1) who satisfies the general conditions of TEKES; 2) whose participation will bring something new to the project; and 3) who is ready to play an active role in a new ecosystem. In addition, projects must fulfil the criteria set out by the board of the CSTI in question" (TIVIT web-page 2010). This last criteria in practice, calls for investment in shares of the limited company in question. As those companies' shares are not sold on stock markets, the decision to increase capital through launching new stocks is always made by the board, and probably not very often. Thus the supposed openness turns into a closed game.

6.7 As stated in the introduction, we understand epistemic communities not as the guardians of the "purity of disciplines" but ideally as both having influence on science policy and having open debates, thus leading toward democratic views as to what the cutting edge in each field might be. The variety in the definitions of epistemic communities create challenges when thinking about the ways they allow for influence, but generally they help in their normativity to put powerful science policy instruments like CSTls in a critical light. We started with Haas' definition of the epistemic community; (a powerful and influential group which necessarily shares the same values and a genuine interest in policy redirection and policy influence (1994). We have taken this to be the most austere definition of an epistemic community. In the Haasian sense, the 
epistemic community in CSTIs would require shared views from all participants - from companies, from the state as the financial backer and from universities - to change the policies for both the research and the company strategies. Given the economic historical view on how companies and corporations shape and define their strategies - due to many external influences, shocks and interdependencies - concerning their production, it might be too naive to assume a direct influence on the ways the epistemic community can change, redirect and reformulate policies.

6.8 Even if we loosen the idea of epistemic community from the Haasian sense towards Knorr-Cetina's or Longino's more open and fluid ideas of epistemic communities, and assume that CSTI board members would jointly form some sort of new epistemic community, or bring their own epistemic communities into the work, we note that, unlike any functioning agora, CSTls do not allow for open or multi-voicing positions for the board members either, due to the organisational structure of the limited company and internally set rules as described above. Conditions for researchers to participate have been set a-priori, and limitations concerning the IPR rights, for example, govern the research activities.

6.9 We have concentrated on a relationship between the academic research community, approximated as the epistemic community, and the agora, where part of the articulation of research agendas and funding decisions are made in the new research landscape. We have used Finland as a case example, and concentrated on showing how epistemic communities lose their possibilities for bottom-up influence when the organisational structure for the agora becomes adopted from the business sector, that closes the openness of the agora, assumed and originally planned through policy. The practical question is crucial not only from the point of view of how epistemic communities exercise their knowledge power, but also in the practical terms of research funding: who decides and from which interests what is being funded as research? What remains to analyse in the future is, for example, the question of how influential the various epistemic communities are at the European level, given the fact that part of research funding is available beyond the national borders.

6.10 Concerning the more theoretical notion of the agora, we conclude that the definition of the agora presented by Nowotny et al. (2001) does not take into account the crucial question of how the agora and its functions are to be organised. Thus the power asymmetries in relation to and within agora remain untouched. The organisation of the implicitly proclaimed agora either relatively well opens up (Research Council of the Academy of Finland) or essentially closes down (CSTI) the possibilities for influence on and access to central epistemic communities. Our example from the Finnish science policy organisation into strategic Centres of Science, Technology and Innovation exemplify the privatisation of knowledge, the commoditised idea of innovation and research, and the closing up of the ways innovations get developed. While CSTIs are undoubtedly platforms where multiple actors 'co-mingle to shape the agenda and use results', it all takes place within the markedly predetermined setting of the limited company with a set Strategic Research Agenda. As an alternative to mode 2 knowledge production with its presumed hybrid models and agoras, Leydersdorff and Etzkowitz (e.g. 1996, 1998, 2000) have developed what they call the Triple Helix model, and, as already pointed out earlier in this article, this model sees 'neo-differentiation' taking place in the relationships between universities, industry and government (Shinn, 2002: 600-606). In further research, it might be fruitful to analyse the CSTls as a kind of neo-differentiated 'exclusive club', where the work of specifically selected scientists is rather minutely steered by market-oriented innovation needs subscribed to by the state. The concept of the epistemic community could then further serve a normative critical function. 
Table 1: Strategic Centres for Science, Technology and Innovation, 2009 (home pages, TEKES, 2009)

\begin{tabular}{|c|c|c|c|c|c|}
\hline CSTI & $\begin{array}{l}\text { CEO, } \\
\text { educati } \\
\text { on }\end{array}$ & $\begin{array}{l}\text { Board, } \\
\text { gender division, } \\
\text { division research/ } \\
\text { business }\end{array}$ & $\begin{array}{l}\text { Shareholders, } \\
\text { university/other }\end{array}$ & $\begin{array}{l}\text { Programme } \\
\text { steering group }\end{array}$ & $\begin{array}{l}\text { Annual R\&D } \\
\text { budget in } \\
\text { full } \\
\text { operation }\end{array}$ \\
\hline FIMECC & $\begin{array}{l}\text { Dr. } \\
\text { (eng.) }\end{array}$ & $\begin{array}{l}9 \text { members: } \\
\text { all male. } \\
2 \text { university/ } 7 \\
\text { business. }\end{array}$ & $\begin{array}{l}30 \text { shareholders, of which } \\
11 \text { from university/ } \\
\text { research institutes. }\end{array}$ & $\begin{array}{l}\text { research programme } \\
\text { \&funding preparation: } \\
5 \text { steering groups, 5-7 } \\
\text { members in each, } \\
\text { majority from } \\
\text { business sector. }\end{array}$ & $70 \mathrm{mE}$ \\
\hline TIVIT & $\begin{array}{l}\text { M.Sc. } \\
\text { (eng.) }\end{array}$ & $\begin{array}{l}12 \text { members: } \\
\text { all male. } \\
3 \text { university } / 9 \\
\text { business. }\end{array}$ & $\begin{array}{l}47 \text { shareholders, } \\
\text { of which } 12 \text { university/ } \\
\text { research institutes. }\end{array}$ & $\begin{array}{l}4 \text { programme areas } \\
\text { with managers; no } \\
\text { description of } \\
\text { procedure. }\end{array}$ & $40 \mathrm{mE}$ \\
\hline SALWE & $\begin{array}{l}\text { M.Sc. } \\
\text { (eng.) }\end{array}$ & $\begin{array}{l}10 \text { members: } \\
2 \mathrm{~F} / 8 \mathrm{M} \\
2 \text { university } / 8 \\
\text { business }\end{array}$ & $\begin{array}{l}28 \text { shareholders, } \\
\text { of which } 12 \text { university/ } \\
\text { research institutes }\end{array}$ & $\begin{array}{l}\text { two programme } \\
\text { managers, two } \\
\text { research programmes } \\
\text { in preparation, consist } \\
\text { of work packages, no } \\
\text { open call }\end{array}$ & $5 \mathrm{me}$ \\
\hline CLEEN & $\begin{array}{l}\text { Dr } \\
\text { (eng.) }\end{array}$ & $\begin{array}{l}9 \text { members: } \\
1 \mathrm{~F} / 8 \mathrm{M} \\
2 \text { university } / 7 \\
\text { business }\end{array}$ & $\begin{array}{l}43 \text { shareholders, } \\
\text { of which } 12 \text { university/ } \\
\text { research institutes }\end{array}$ & $\begin{array}{l}5 \text { programme areas, } \\
\text { R\&D council } \\
\text { representing } \\
\text { shareholders decides }\end{array}$ & $40 \mathrm{mE}$ \\
\hline $\begin{array}{l}\text { Forest } \\
\text { Cluster }\end{array}$ & $\begin{array}{l}\text { Lic.Sc. } \\
\text { (chem.) }\end{array}$ & $\begin{array}{l}11 \text { members: } \\
\text { all male. }\end{array}$ & $\begin{array}{l}15 \text { shareholders, } \\
\text { of which } 4 \text { university/ } \\
\text { research institutes }\end{array}$ & $\begin{array}{l}\text { board makes funding } \\
\text { decisions }\end{array}$ & $40 \mathrm{me}$ \\
\hline $\begin{array}{l}\text { RYM- } \\
\text { CSTI }\end{array}$ & $\begin{array}{l}\text { Dr. } \\
\text { (eng.) }\end{array}$ & $\begin{array}{l}11 \text { members: } \\
\text { all male. } \\
2 \text { research institutes } \\
/ 9 \text { business }\end{array}$ & $\begin{array}{l}52 \text { shareholders, } \\
\text { of which } 4 \text { university/ } \\
\text { research institutes }\end{array}$ & $\begin{array}{l}3 \text { research } \\
\text { programmes in } \\
\text { preparation, no } \\
\text { information of the } \\
\text { procedure }\end{array}$ & $20 m E$ \\
\hline
\end{tabular}

Table 2: Finnish science policy documents analyzed for the article.

Finland's competence, openness and renewability (2004), Prime Minister's Office: Publications 26/2004.

Edita Prima Oy, Helsinki.

Available: <http://www.wnk.fi/julkaisukansio/ 2004/j19-26-osaava-avautuva-uudistuva-suomi/pdf/en.pdf>

Read 1.11.2009.

Government Resolution on the Structural Development of The Public Research System

- Report (2005)

Available: <http://www.minedu.fi/OPM/Tiede/tiede-_ja_teknologianeuvosto/ erillisraportit/liitteet/> Read

1.11.2009.

Internationalization of Finnish Education, Research and Innovation (2009) Research and Innovation Council of Finland, Helsinki University Press, Helsinki.

Available: <http://www.minedu.fi/ export/sites/default/OPM/Tiede/tutkimus-_ja_innovaationeuvosto/ erillisraportit/KVstrategia_Eng.pdf>. Read 1.11.2009.

Knowledge, Innovation and internationalization. (2003)

Science and Technology Policy council of Finland. Helsinki.

Science, Technology, Innovation (2006)

Science and Technology Policy Council of Finland. Government. Helsinki. 


\section{Notes}

${ }^{1}$ Classically defined as an open place of any public assembly, in a modern sense 'agora' has also come to mean ideas close to the original metaphor of an open marketplace as used by Gibbons (1999). Presently 'agora' as a metaphor can be understood as an open 'container' for researchers, networks and institutions such as universities, conferences, journals and research councils that exist to certify scientific knowledge claims. (Barré, 2001; Frederiksen et al., 2003).

${ }^{2}$ Due to a lack of space, we are not able to go into detail on several of the problems related to Nowotny's idea of transdisciplinarity.

${ }^{3}$ Even if the two issues, the formulation of CSTIs and the renewal of the University Act, are related and are both part of the Government's national innovation and science policy, due to a lack of space, we will not discuss in detail the 2009 renewal of the University Act. The new Act will change the legal position of universities, increasing, among other things, their financial flexibility and reorganising universities' collaboration and their merging into new entities.

${ }^{4}$ The Science and Technology Policy Council, now renamed as the Research and Innovation Council and chaired by the Prime Minister, commissioned the reports on Finland and its position in the world (Council of State 19/2004), as well as several others, focusing on the competitiveness of Finnish science and technology research.

${ }^{5}$ This is, in fact, also clearly present in the Health \& Wellbeing CSTI (SalWe). In the Finnish presentation slides on their web-pages, the programme states: "Companies first decide what to research, universities then decide how to research it." (authors' own translation,

http://www.salwe.org/tiedostot/pdf/tilannekatsaus24.3.2010.pdf ). This is not, interestingly enough, similarly expressed in the English translation of the slides on the same web-page.

\section{Acknowledgements}

Support for this work was provided by Academy of Finland Research project funding and Academy Professorship funding. We wish to thank the anonymous referees for their invaluable feedback on an earlier version of this paper.

\section{References}

ACADEMY OF FINLAND (2009) Background to CSTls, http://www.aka.fi/en-gb/A/Science-insociety/Strategic-Centres-for-Science-Technology-and-Innovation/ Accessed 1.6.2009

BARRÉ, R. (2001) The Agora model of innovation systems: S\&T indicators for a democratic knowledge society, Research Evaluation, Vol. 10, No. 1, pp. 13-18

DEEM, R., HILLYARD, S. and REED, M. (2007) Knowledge, Higher Education, and the new Managerialism. The Changing Management of UK Universities, Oxford: Oxford University Press [doi:10.1093/acprof:oso/9780199265909.001.0001]

ELZINGA, A. (1993) 'Antarctica: The Construction of a Continent by and for Science', in CRAWFORD, E., SHINN, T. and SÖRLIN, S. (editors) Denationalizing Science: The Contexts of International Scientific Practice, Dordrecht: Kluwer Academic Publishers

ELZINGA, A. (2004) 'The New Production of Reductionism in Models Relating to Research Policy', in GRANDIN, K., WORMBS, N and WIDMALM, S. (editors) The Science-Industry Nexus: History, Policy, Implications, Sagamore Beach, MA: Science History Publications

ETZKOWITZ, H. and LEYDESDORFF, L. (2000) 'The Dynamics of Innovation: From National Systems and 'Mode 2' to a Triple Helix of University-Industry-Government Relations', Research Policy, Vol. 29, No. 2, pp. 109-123 [doi:10.1016/S0048-7333(99)00055-4]

FELT, U. (editor) (2009) Knowing and Living in Academic Research. Prague: Institute of Sociology of the Academy of Sciences of the Czech Republic. 
FREDERIKSEN, L.F., HANSSON, F. and WENNEBERG, S.B. (2003) 'The Agora and the Role of Research Evaluation', Evaluation, Vol. 9, No. 2, pp. 149-172 [doi:10.1177/1356389003009002003]

FIMECC SRA (2009) Competitiveness Through Research, http://www.fimecc.com/fi/images/a/a8/ FIMECC_strateginen_tutkimusagenda.pdf Accessed 10.7.2009

FINLAND'S COMPETENCE, OPENNESS AND RENEWABILITY (2004) Prime Minister's Office: Publications 26/2004. Helsinki. Available: http://www.vnk.fi/julkaisukansio/2004/j19-26-osaava-avautuvauudistuva-suomi/pdf/en.pdf Accessed 1.11.2009.

FULLER, S. (2002) Knowedge Management Foundations. Woburn, MA: Butterworth-Heinemann

GIBBONS, M., LIMOGES, C., NOWOTNY, H., SCHWARTZMAN, S., SCOTT, P. and TROW, M. (1994) The New Production of Knowledge: The Dynamics of Science and Research in Contemporary Societies. London: Sage

HAAS, P. (1992) 'Introduction: Epistemic Communities and International Policy Coordination', International Organization, Vol. 46, No. 1 (Winter, 1992), pp. 1-35 [doi:10.1017/S0020818300001442]

INTERNATIONALIZATION OF FINNISH EDUCATION, RESEARCH AND INNOVATION (2009) Research and Innovation Council of Finland, Helsinki University Press, Helsinki. Available:

http://www.minedu.fi/export/sites/default/OPM/Tiede/tutkimus-ja_innovaationeuvosto /erillisraportit/KVstrategia_Eng.pdf . Accessed 1.11.2009.

JASANOFF, S. (1998) 'Expert Games in Silicone Gel Breast Implant Litigation', in FREEMAN, M. and REECE, H. (editors) Science in Court, London: Dartmouth

JASANOFF, S. (2006) 'Ordering Knowledge, Ordering Society', in JASANOFF, S. (editor), States of Knowledge. The Co-Production of Science and Social Order, Abington, UK, New York, US: Routledge

KITCHER, P. (2001) Science, Truth, and Democracy. Oxford, UK, New York, US: Oxford University Press [doi:10.1093/0195145836.001.0001]

KNORR-CETINA, K. (1999) Epistemic Cultures: How the Sciences Make Knowledge, Cambridge, MA, London, England: Harvard University Press

KNOWLEDGE, INNOVATION AND INTERNATIONALIZATION (2003) Science and Technology Policy council of Finland. Helsinki

LATOUR, B. and WOOLGAR, S. (1991) Laboratory Life: The Construction of Scientific Facts , Princeton, $\mathrm{NJ}$ : Princeton University Press

LEYDESDORFF, I. and ETZKOWITZ, H. (1996) 'Emergence of a Triple Helix of University-IndustryGovernment Relations', Science and Public Policy, Vol. 23, pp. 279-286

LEYDESDORFF, I. and ETZKOWITZ, H. (1998) (eds.) A Triple Helix of University-Industry-Government Relations: The Future Location of Research?, New York: Science Policy Institute, State University of New York.

LONGINO, H.E. (2002) The Fate of Knowledge. Princeton: Princeton University Press.

MINISTRY OF EDUCATION (2005a) 'Press release: Decision in Principle: Education and Research Must Become More International', http://www.minedu.fi/OPM/Tiedotteet/2005/4/ valtioneuvoston _periaatepaatos_koulutuksen_tutkimuksen_ja_inno?lang=fi\&extra_locale=en. Accessed 27.6.2009

MINISTRY OF EDUCATION (2005b) 'The Government Resolution on the Structural Development of the Public Research System', http://www.minedu.fi/export/sites/default/OPM/Tiede /tiedepolitiikka/ liitteet/Periaatepaatos07042005.pdf Accessed 1.6.2009

NELSON, R.R. (1993) (Editor) National Innovation Systems: A Comparative Study, New York: Oxford Univ. Press

NOWOTNY, H., SCOTT, P. and GIBBONS, M. (2001) Re-Thinking Science. Knowledge and the Public in an Age of Uncertainty. Cambridge: Polity Press

NOWOTNY, H., SCOTT, P. and GIBBONS, M. (2003) 'Mode 2' Revisited: The New Production of Knowledge', Minerva, Vol. 41, No. 3, pp. 179-194 [doi:10.1023/A:1025505528250]

NOWOTNY, H. (2003) The Potential of Transdisciplinarity .

http://www.interdisciplines.org/interdisciplinarity/papers/5/printable/discussions , Accessed 17.6.2009 
PESTRE, D. (2000) 'The Production of Knowledge between Academies and Markets: A Historical Reading of the Book, The New Production of Knowledge', Science, Technology and Society, Vol. 5, No. 2, pp. 169181 [doi:10.1177/097172180000500202]

PESTRE, D. (2003) 'Regimes of Knowledge Production in Society: Towards a More Political and Social Reading', Minerva, Vol. 41, No. 3, pp. 245-261 [doi:10.1023/A:1025553311412]

POWER, M. (1997) The Audit Society. Rituals of Verification, Oxford: Oxford University Press

PROJECT ASSESSMENT FORM (2009) FIMECC project assessment form http://www.fimecc.com/fi/ index.php/ Tutkimusstrategia Accessed 11.7.2009

RIP, A. and VAN DER MEULEN, B. (1996) 'The Post-Modern Research System', Science and Public Policy Vol. 23, No. 6, pp. 343-352

SHINN, T. (2002) 'The Triple Helix and New Production of Knowledge: Prepackaged Thinking on Science and Technology', Social Studies of Science, Vol. 32, No. 4, pp. 599-614 [doi:10.1177/0306312702032004004]

SCIENCE, TECHNOLOGY, INNOVATION (2006), Science and Technology Policy Council of Finland. Government. Helsinki.

SLAUGHTER, S. and LESLIE, L. (1997) Academic Capitalism: Politics, Policies and the Entrepreneurial University, Baltimore and London: The John Hopkins University Press

SOLOMON, M. (2001) Social Empiricism, Cambridge, MA, London, England: The MIT Press

STRATEGIC CENTRES OF EXCELLENCE (2006) Report by Research and Innovation Council. Ministry of Education, http://www.minedu.fi/export/sites/default/OPM/Tiede/tutkimus-

ja_innovaationeuvosto/TTN/erillisraportit/liitteet/Strategic_Centres_of_Excellence_2006.pdf Accessed 15.9.2009.

STATISTICS FINLAND (2008) R\&D statistics, http://www.stat.fi/til/tkke/2007/tkke_2007_2008-10-

23_tie_001_en.html Accessed 3.6.2009

TEKES (2009). TEKES Annual Review. Finland. TEKES.

TIVIT WEBPAGE (2010), http://www.tivit.fi/en/participation Accessed 1.3.2010

WEBStER, A. (2007) 'Crossing Boundaries: Social Science in the Policy Room', Science, Technology \& Human Values, Vol. 32, pp. 458-478 [doi:10.1177/0162243907301004]

ZIMAN, J. (1994) Prometheus Bound: Science in a Dynamic Steady State, Cambridge: Cambridge Univ. Press [doi:10.1017/CBO9780511585067] 